\title{
ETNOZOOLOGI MASYARAKAT DAYAK JELAI HULU EMBULU LIMA DI DESA MEKAR UTAMA KECAMATAN KENDAWANGAN KABUPATEN KETAPANG
}

\author{
(Etnozoologi Dayak Jelai Hulu Embulu Lima Community In Mekar Utama Vilage, \\ Kendawangan Subdistrict, Ketapang Regency)
}

\author{
Eko Sunaryo, M. Sofwan Anwari, Ahmad Yani \\ Fakultas Kehutanan Universtas Tanjungpura Pontianak. Jl. Daya Nasional Pontianak 78124 \\ Email: sunaryoeko74@gmail.com
}

\begin{abstract}
The use of fauna has been carried out by various ethnic groups in Kalimantan for a long time to fulfill their daily needs, one of which is as a source of food, medicine, ritual facilities, mysticism and art. The Dayak Jelai Hulu Embulu Lima tribe located in Mekar Utama Village, Kendawangan District are one of the original ethnic groups of West Kalimantan, also have diversity in the use of fauna both for food, medicine, traditional and supernatural ceremonies. The purpose of this study is to list the types of animals that are used and examine the use of animals. Data collection techniques are done by in-depth interviews with selected respondents using survey methods. The selection of respondents was carried out using snowball sampling techniques. Respondents in this study were 9 people. The interview results obtained as many as 48 types of data used in the village. Utilization varies starting from the utilization of consumption of as many as 35 animals, which has 9 artistic values, for the treatment of 12 animals, as much as 4 mystical animals, and for rituals as many as 3 animals. Based on the high percentage of species of animals utilized by the Embulu Lima Upper Barley community, namely consumption. The high percentage of consumption utilization is $58 \%$, the part that is used is meat and the way it is processed is more cooked and fried. Meeting the needs of the most protein is from game animals. Utilization of animals for the treatment of ways such as, among others, drunk, smeared, and eaten. Processing methods include drying, scraping, diluting and cooking.
\end{abstract}

Keywords: Dayak Jelai Hulu Embulu Lima, Ethnozoolgy, Utilization.

\section{PENDAHULUAN}

Kekayaan flora dan fauna di Kalimantan dapat dipelihara sebagai bagian dari kekayaan sumberdaya alam. Keberadaan flora dan fauna tidak dapat dipisahkan dengan kehidupan manusia. Manusia merupakan satuan kehidupan yang memanfaatkan berbagai sumberdaya di sekitar mereka untuk memenuhi kebutuhan hidupnya (Suparlan, 2005). Suku-suku asli yang mendiami suatu tempat sangat mengenal sumberdaya hayati di lingkungan yang telah beradaptasi dan terlatih untuk memanfaatkan flora dan fauna (Indrawan et al. 2007). Para ilmuan modern banyak belajar dari masyarakat lokal dalam memahami kekayaan keanekaragaman flora maupun fauna dan mulai menggali pengetahuan lokal yang telah berabadabad berbagai suku asli suatu tempat, salah satunya suku asli Kalimantan Barat.

Menurut Bappenas (2003) bahwa salah satu masalah kehutanan yang teridentifikasi pada bioregion Kalimantan adalah kurang lengkapnya data base 
mengenai potensi keanekaragaman hayati.

Data base mengenai potensi keanekaragaman hayati khususnya satwa, baru dilakukan pada tingkat keanekaragaman jenis, belum sampai pada manfaat khusus satwa bagi manusia. Pemanfaatan terhadap satwa yang dilindungi dikhawatirkan akan mempercepat laju kepunahan satwa jika tidak dilakukan perencanaan pengelolaan yang baik.

Pemanfaatan flora dan fauna telah dilakukan oleh berbagai etnis yang ada di kalimantan sejak dulu untuk memenuhi kebutuhan hidupnya, salah satunya sebagai sumber bahan pangan, obatobatan, sarana ritual kebudayaan dan kepentingan ekonomi subsisten. Ragam pemanfaatan satwa merupakan implikasi dari beragamnya etnis, baik dalam hal jenis satwa yang dimanfaatkan, bentuk pemanfaatan maupun cara memanfaatkannya. Masyarakat pedalaman kalimantan yang hidup di dalam maupun di sekitar hutan masih menggantungkan hidupnya pada hutan yang ada di sekitar mereka. Keragaman dalam pemanfaatan satwa mendorong terbentuknya pola yaitu sebuah sistem atau cara kerja yang tetap dalam memanfaatkan berbagai jenis satwa. Hal ini berkaitan erat dengan proses interaksi yang berkembang antara etnis tertentu yang tinggal di sekitar hutan dengan alam lingkungannya dari waktu ke waktu.

Suku dayak yang berada di Desa Mekar Utama, Kecamatan Kendawangan, Kabupaten Ketapang merupakan salah satu etnis asli Kalimantan Barat. Masyarakat Dayak Jelai Hulu Embulu
Lima di Desa Mekar Utama ini juga memiliki keanekaragaman dalam pemanaatan fauna baik untuk bahan pangan, obat-obatan, upacara adat dan supranatural. Kajian etnozoologi ini penting untuk dilakukan mengingat pengetahuan lokal yang semakin terdegradasi akibat kemajuan zaman. Studi etnozoologi ini dapat memberikan kontribusi yang besar dalam proses pengenalan sumberdaya alam hewani yang ada di suatu wilayah melalui kegiatan pengumpulan data pengetahuan lokal masyarakat setempat. Kajian etnozoologi oleh masyarakat di Desa Mekar Utama, Kecamatan Kendawangan, Kabupaten Ketapang ini perlu dilakukan untuk menunjang upaya pelestarian dan pemanfaatannya. Tujuan Penelitian ini yaitu: 1. Mendata jenis-jenis hewan apa saja yang dimanfaatkan oleh Masyarakat Dayak Desa Mekar Utama, Kecamatan Kendawangan, Kabupaten Ketapang dan 2. Mengkaji pemanfaatan hewan oleh Masyarakat Dayak Desa Mekar Utama, Kecamatan Kendawangan, Kabupaten Ketapang

\section{METODE PENELITIAN}

Penelitian ini dilaksanakan di Dusun Silingan, Dusun Sukaria dan Dusun Kelukublantak, Desa Mekar Utama, pada tanggal 30 Januari sampai 17 Februari 2019. Teknik pengumpulan data dilakukan dengan wawancara mendalam terhadap responden yang terpilih dengan menggunakan metode survey. Pemilihan responden ini dilakukan dengan menggunakan teknik snowball sampling yaitu dengan menentukan responden kunci untuk kemudian menentukan responden 
lainnya berdasarkan informasi dari responden sebelumnya, demikian juga untuk seterusnya. Analisa data yang digunakan adalah metode Deskriptif Kualitatif, yaitu mendeskrifsikan data yang dikumpulkan berupa kata-kata, gambar dan bukan angka.

\section{HASIL DAN PEMBAHASAN}

Jenis Satwa Yang Dimanfaatkan

Berdasarkan hasil wawancara yang dilakukan di Desa Mekar Utama Kecamatan Kendawangan Kabupaten Ketapang diperoleh sebanyak 9 orang. Wawancara dilakukan untuk memperoleh data mengenai jenis satwa yang diketahui ada 48 jenis satwa dari 45 famili yang dimanfaatkan oleh masyarakat. Familifamili tersebut rata-rata setiap famili hanya terdiri atas satu spesies, kecuali untuk famili Cervidae, Columbidae, Muscicapidae, Trionychidae, dan Gekkonidae yang memiliki masingmasing dua spesies. Berdasarkan tingkat kelas maka diperoleh delapan kelas satwa yang dimanfaatkan yaitu Mamalia, Aves, Amfibi, Reptil, Insecta, Molusca, Pisces, dan Crustacea. Informasi jenis satwa dapat dilihat pada tabel 1 .

Tabel 1. Jenis Satwa Yang Dimanfaatkan Oleh Masyarakat Dayak Jelai Hulu Embulu Lima di Desa Mekar Utama (Animal Spesies that Utilized Dayak Jelai Hulu Embulu Lima in Mekar Utama Village)

\begin{tabular}{|c|c|c|c|c|c|c|c|c|}
\hline \multirow[b]{2}{*}{ No } & \multicolumn{2}{|r|}{ Jenis Satwa } & \multicolumn{4}{|c|}{ Peruntukan } & \multicolumn{2}{|c|}{ Status Konservasi } \\
\hline & Nama Indonesia & Nama IImiah & $\mathbf{K}$ & & NS & RMP & $\begin{array}{c}\text { CITES APPENDICE } \\
\text { (2018) }\end{array}$ & $\begin{array}{l}\text { IUCN } \\
(2018)\end{array}$ \\
\hline \multicolumn{9}{|c|}{ Mamalia } \\
\hline 1 & Babi & Sus barbatus & $\sqrt{ }$ & & $\sqrt{ }$ & $\sqrt{ }$ & - & - \\
\hline 2 & Anjing & Canis lupus & $\sqrt{ }$ & & & $\sqrt{ }$ & - & - \\
\hline 3 & Kijang & Muntiacus muntjak & $\sqrt{ }$ & & $\sqrt{ }$ & & - & DD \\
\hline 4 & Rusa & Cervus unicolor & $\sqrt{ }$ & & $\sqrt{ }$ & & - & DD \\
\hline 5 & Munsang & Paradoxurus hermaphroditus & $\sqrt{ }$ & & & & III & $\mathrm{LC}$ \\
\hline 6 & Kera & Macaca fascicularis & $\sqrt{ }$ & & $\sqrt{ }$ & & - & $\mathrm{LC}$ \\
\hline 7 & Landak & Hystric brachyura & $\sqrt{ }$ & $\sqrt{ }$ & & & - & $\mathrm{LC}$ \\
\hline 8 & Kucing Hutan & Pardofelis marmorata & $\sqrt{ }$ & & & & II & $\mathrm{LC}$ \\
\hline 9 & Kancil & Tragulus khancil & $\sqrt{ }$ & & & & - & NT \\
\hline 10 & Tupai & Tupai agracilis & $\sqrt{ }$ & & & & - & $\mathrm{LC}$ \\
\hline 11 & Beruang & Helarctos malayanus & $\sqrt{ }$ & $\sqrt{ }$ & & & - & $\mathrm{LC}$ \\
\hline 12 & Kelelawar & Pteropus admiralitatum & $\sqrt{ }$ & $\sqrt{ }$ & & & - & $\mathrm{LC}$ \\
\hline 13 & Terenggiling & Manis javanica & $\sqrt{ }$ & & & & I & $\mathrm{LC}$ \\
\hline 14 & Kukang & Nycticebus coucang & $\sqrt{ }$ & & & & - & $\mathrm{LC}$ \\
\hline \multicolumn{9}{|c|}{ Aves } \\
\hline 15 & Enggang & Buceros vigil & & $\sqrt{ }$ & $\sqrt{ }$ & & I & NR \\
\hline 16 & Tengkukur & Spilopelia chinensis & & & $\sqrt{ }$ & & - & $\mathrm{LC}$ \\
\hline 17 & Punai & Treron capellei & $\sqrt{ }$ & & & & - & $\mathrm{LC}$ \\
\hline 18 & Ruai & Argusianus argus & & & $\sqrt{ }$ & & I & $\mathrm{LC}$ \\
\hline 19 & Burung Hantu & Otus magicus & & & & $\sqrt{ }$ & - & $\mathrm{LC}$ \\
\hline 20 & Ayam & Gallus gallus domesticus & $\sqrt{ }$ & & & $\sqrt{ }$ & - & - \\
\hline 21 & Elang & Spizaetus cirrhatus & & & $\sqrt{ }$ & & - & $\mathrm{LC}$ \\
\hline 22 & Murai Batu & Copsychus malabaricus & & & & $\sqrt{ }$ & II & NT \\
\hline
\end{tabular}




\begin{tabular}{|c|c|c|c|c|c|c|c|}
\hline \multirow[b]{2}{*}{ No } & \multicolumn{2}{|r|}{ Jenis Satwa } & \multicolumn{3}{|c|}{ Peruntukan } & \multicolumn{2}{|c|}{ Status Konservasi } \\
\hline & Nama Indonesia & Nama Ilmiah & $\mathbf{K ~ P}$ & NS & RMP & $\begin{array}{c}\text { CITES APPENDICE } \\
(\text { (2018) }\end{array}$ & $\begin{array}{l}\text { IUCN } \\
(2018) \\
\end{array}$ \\
\hline 23 & Burung Kacer & Copsychus saularis & & $\sqrt{ }$ & & III & $\mathrm{LC}$ \\
\hline 24 & Kareo Padi & Amaurornis phoenicccurus & $\sqrt{ }$ & & & - & - \\
\hline \multicolumn{8}{|c|}{ Amfibi } \\
\hline 25 & Katak & Fejervaya cancivora & $\sqrt{ }$ & & & - & - \\
\hline \multicolumn{8}{|c|}{ Reptil } \\
\hline 26 & Cicak & Hemidactylus platyurus & & & $\sqrt{ }$ & - & - \\
\hline 27 & Kadal Pohon & Dasia olivacea & $\sqrt{ }$ & $\sqrt{ }$ & & - & - \\
\hline 28 & Labi-labi & Amyda cartilaginea & $\sqrt{ } \sqrt{1}$ & & & - & $\mathrm{LC}$ \\
\hline 29 & Kura-kura & Manouria emys & $\sqrt{ } \sqrt{ }$ & & & - & $\mathrm{LC}$ \\
\hline 30 & Ular Phyton & Phyton curtus & $\sqrt{ } \sqrt{ }$ & & & II & $\mathrm{LC}$ \\
\hline 31 & Tokek & Gekko gecko & $\sqrt{ }$ & $\sqrt{ }$ & & II & NT \\
\hline 32 & Biawak & Varanus salvator & $\sqrt{ } v$ & & & - & $\mathrm{LC}$ \\
\hline \multicolumn{8}{|c|}{ Insecta } \\
\hline 33 & Ulat sagu & Rhynchophorus ferruginesus & $\sqrt{ }$ & & & - & - \\
\hline 34 & Lebah & Apis sp & $\sqrt{ }$ & $\sqrt{ }$ & & - & - \\
\hline 35 & Kelulut & Trigona $s p$ & $\sqrt{ }$ & $\sqrt{ }$ & & - & - \\
\hline 36 & Tonggeret & Tibicen linnei & $\sqrt{ }$ & $\sqrt{ }$ & $\sqrt{ }$ & - & - \\
\hline \multicolumn{8}{|c|}{ Molusca } \\
\hline 37 & Bekicot & Achatina fulica & $\sqrt{ }$ & & & - & - \\
\hline 38 & Keong Mas & Pomacea canaliculata & $\sqrt{ }$ & & & - & - \\
\hline \multicolumn{8}{|c|}{ Pisces } \\
\hline 39 & Ikan Lele & Clarias batracus & $\sqrt{ }$ & & $\sqrt{ }$ & - & $\mathrm{LC}$ \\
\hline 40 & Ikan Manyung & Plicofollis crossocheilos & $\sqrt{ }$ & & & - & $\mathrm{LC}$ \\
\hline 41 & Ikan Baung & Mystus nemurus & $\sqrt{ }$ & & & - & $\mathrm{LC}$ \\
\hline 42 & Ikan Gurame & Osphronemus goramy & $\sqrt{ }$ & & & - & $\mathrm{LC}$ \\
\hline 43 & Ikan Sembilang & Euristhmus microceps & $\sqrt{ }$ & & & - & $\mathrm{LC}$ \\
\hline 44 & Ikan Gabus & Chana striata & $\sqrt{ }$ & $\sqrt{ }$ & & - & $\mathrm{LC}$ \\
\hline 45 & Ikan Betok & Anabas testudineus & $\sqrt{ }$ & & & - & - \\
\hline 46 & Belut & Anabas testudineus & $\sqrt{ }$ & & & - & $\mathrm{LC}$ \\
\hline \multicolumn{8}{|c|}{ Crustacea } \\
\hline 47 & Udang & Macrobrachium rosenbergii & $\sqrt{ }$ & & & - & - \\
\hline 48 & Kepiting & Parathelpusa convexa & $\sqrt{ }$ & & & - & - \\
\hline
\end{tabular}

Keterangan: K: Konsumsi, P: Pengobatan, NS: Nilai Seni, RMP: Ritual Mistis (Pertanda), LC: Least Concern; DD: Data Deficient; CR: Critically Endangered; NT: Near Threatened; (-) tidak masuki daftar konservasi;

Kelas terbanyak yang dimanfaatkan adalah jenis Mamalia yang terdiri atas 14 spesies. Pemanfaatan hewan oleh masyarakat Dayak Jelai Hulu Embulu Lima bervariasi mulai dari pemanfaatan konsumsi, pengobatan, ritual adat atau mistis, dan nilai seni. Presentase pemanfaatan satwa dapat dilihat pada tabel 2. 
Tabel 2. Presentase Pemanfaatan Satwa (Percentage of Animal Utilization)

\begin{tabular}{cc}
\hline Jenis Pemanfaatan & Presentase (\%) \\
\hline Konsumsi & 58 \\
Nilai Seni & 14 \\
Pengobatan & 17 \\
Mistis & 6 \\
Ritual & 5 \\
\hline
\end{tabular}

Pemanfaatan terbanyak untuk kebutuhan konsumsi sebanyak 35 spesies dengan persentasae $58 \%$ dan pemanfaatan satwa yang sedikit dimanfaatkan yaitu pada bagian ritual dengan presentase $5 \%$.

\section{Pemanfaatan Satwa untuk Konsumsi}

Berdasarkan penelitian yang dilakukan melalui wawancara diperoleh satwa yang dimanfaatkan untuk konsumsi terdapat 35 jenis satwa oleh masyarakat Dayak Jelai Hulu Embulu Lima di Desa Mekar Utama. Bagian yang dimanfaatkan adalah daging dan cara pengolahannya lebih banyak dimasak kuah dan digoreng. Daging merupakan sumber protein hewani yang sangat bermanfat bagi perkembangan tubuh manusia. Bagi masyarakat Dayak Jelai Hulu Embulu Lima Desa Mekar Utama tidak ada pantangan memakan atau mengkonsumsi hewan, kecuali pantangan adat dan hewan-hewan yang beracun. Pemenuhan kebutuhan protein paling banyak adalah dari hewan buruan. Hewan buruan yang utama adalah kijang (Muntiacus muntjak), babi hutan (Sus barbatus), dan biawak (Varanus salvator). Masyarakat Dayak Jelai Hulu Embulu Lima berburu menggunakan parang, senapang angin, dan tombak dengan bantuan anjing untuk melacak hewan buruan.
Kebiasaan masyarakat dalam mengkonsumsi hewan buruan ini dapat dilihat dari sisa hewan buruannya seperti, taring babi hutan (Sus barbatus), tengkorak kijang (Muntiacus muntjak) dan tengkorak rusa (Curvus unicolor).

\section{Pemanfaatan Satwa untuk Pengobatan}

Pemanfaatan lain hewan di Dayak Jelai Hulu Embulu Lima adalah sebagai obat. Masyarakat masih sangat mempercayai bahwa bagian tertentu dari hewan dapat digunakan sebagai obat atau atau sarana pengobatan. Informasi ini diperoleh dari hasil wawancara di wilayah Desa Mekar Utama Dayak Jelai Hulu Embulu Lima.

Landak (Histryx brachyura), pemanfaatan hewan landak yang digunakan sebagai pengobatan, bagian yang dimanfaatkan yaitu usus halus dan duri landak. Usus halus dimanfaatkan sebagai bahan pengobatan yang digunakan oleh masyarakat Dayak Jelai Hulu Embulu Lima dalam mengobati jenis penyakit seperti tipes dan malaria. Cara pengolahan terlebih dahulu usus halus dikeringkan disinar matahari maupun diatas Parak atau perapian agar kering sebagai upaya pengawetan. Usus yang sudah kering direndam kedalam air hangat, hasil rendaman dari usus 
landak dapat diminum langsung, penggunaan cara ini dapat dipercaya menyembuhkan penyakit jenis tipes maupun malaria. Pemanfaatan duri landak juga dipercaya dapat mengobati masuk angin, cara pengolahan dari duri landak terlebih dahulu dikeringkan, pada bagian duri landak dikikis kemudian serbuk tersebut dicampur dengan air dan ditempelkan ke bagian tubuh yang sakit. Pengobatan ini dipercaya bahwa angin akan keluar pada bagian yang ditempeli dengan serbuk landak tersebut.

Beruang (Helarctos malayanus), pemanfaatan hewan beruang yang digunakan sebagai pengobatan, bagian yang dimanfaatkan yaitu taring, kulit, dan empedu. Taring dimanfaatkan sebagai bahan pengobatan yang digunakan oleh masyarakat Dayak Jelai Hulu Embulu Lima dalam mengobati sakit perut. Cara pemanfaatannya cukup sederhana yaitu dengan meminum langsung air rendaman taring beruang dengan air hangat. Kulit hewan beruang dimanfaatkan sebagai bahan pengobatan untuk mengatasi pendarahan pada wanita. Cara pengolahannya dengan cara duduk diatas kulit beruang untuk menghentikan pendarahan.

Empedu merupakan bagian organ tubuh hewan yang dimanfaatkan sebagai obat oleh masyarakat Dayak Jelai Hulu Embulu Lima dalam mengobati keracunan makanan maupun racun pada hewan yang berbisa. Cara pengolahannya yaitu dengan cara dikeringkan terlebih dahulu agar empedu tidak membusuk saat dikonsumsi, setelah dikeringkan empedu bisa digunakan dengan cara mengambil sedikit bagian empedu dengan jarum untuk dicampurkan ke air hangat dan kemudian diminum langsung dengan air hangat.

Pemanfaatan burung enggang yang digunakan sebagai pengobatan, selain untuk pengobatan burung ini dimanfaatkan untuk keperluan adat dan dikonsumsi dagingnya. Burung Tinggang penagung atau dalam bahasa Dayak Jelai Hulu Embulu Lima burung enggang yang dimanfaatkan yaitu bagian gading dan paruh dalam mengobati keracunan makanan maupun racun dari hewan yang berbisa. Cara pengolahannya terlebih dahulu gading burung enggang dikeringkan, kemudian dikikis untuk diambil serbuk pada bagian yang dikikis, serbuk tersebut dicampur ke dalam air dan langsung diminum.

Kadal (Dasia olivacea), pemanfaatan hewan kadal yang digunakan sebagai bahan pengobatan, dengan mengkonsumsi daging hewan ini dipercaya dapat menyembuhkan jenis penyakit seperti penyakit kulit. Pengolahannya cukup sederhana dengan cara dimasak ataupun dengan cara pengolahan lainnya. Menurut Pilatus (2017), masyarakat suku Dayak Kanayant juga memfaatkan Epak atau dalam bahasa Dayak Kanayant kadal pohon borneo dalam mengobati asma.

Labi-labi (Amyda cartilaginea), Kura-kura (Manouria emys), Phyton (Phyton curtus), pemanfaatan hewanhewan ini yang digunakan yaitu bagian 
lemak. Masyarakat Dayak Jelai Hulu Embulu Lima menggunakan lemak hewan ini sebagai minyak urut. Minyak urut hewan tersebut dipercaya dapat mengobati patah tulang, sakit badan maupun memar akibat benturan. Labilabi juga dimanfaatkan empedunya untuk pengobatan dalam kepercayaan masyarakat Dayak Belangin di Desa Mu'un dalam mengobati berbagai penyakit seperti asma dan malaria (Heningsih, 2018).

Tokek (Gekko gecko), pemanfaatan hewan ini dengan cara mengkonsumsi daging tokek, daging tokek ini menurut masyarakat Dayak Jelai Hulu Embulu Lima dapat mengobati jenis penyakit seperti penyakit kulit maupun asma. Pengolahannya cukup sederhana hanya dengan memasak daging tokek yang telah dibersihkan. Tokek merupakan hewan yang paling sering dimanfaatkan oleh masyarakat di kelurahan Dinoyo Malang untuk pengobatan penyakit sesak nafas maupun gatal (Zayadi, 2010).

Biawak (Varanus salvator), Kelelawar (Pteropu admiralitatum), empedu yang dimanfaatkan sebagai obat oleh masyarakat Dayak Jelai Hulu Embulu Lima merupakan bagian organ tubuh hewan ini. Empedu pada hewan ini telah digunakan dalam mengobati penyakit seperti asma, flu, hepatitis dan racun makanan. Cara pengolahan terlebih dahulu empedu dikeringkan agar tidak membusuk dan menjaga ketahanan empedu, empedu yang telah kering bisa digunakan langsung dengan mencungkil bagian empedu menggunakan jarum, kemudian mencampur bagian ini kedalan air untuk langsung diminum.

Kelulut (Trigona sp), Lebah (Apis $s p$ ), madu bagian yang digunakan sebagai obat oleh masyarakat Dayak Jelai Hulu Embulu Lima merupakan bagian dari jenis hewan Insecta. Madu pada hewan ini dapat mengobati segala jenis penyakit didalam tubuh maupun diluar tubuh. Cara pemanfaatannya dengan meminum langsung madu dan dicampur tanaman herbal maupun dioleskan pada bagian tubuh.

Ikan gabus (Channa striata), ikan gabus merupakan jenis ikan predator yang hidup di air tawar, masyarakat Dayak Jelai Hulu Embulu Lima memanfaatkan jeniskan ikan untuk mengobati bekas luka operasi, cara pengolahan yaitu dengan cara mengonsumsi daging ikan gabus yang telah dimasak.

\section{Pemanfaatan Satwa untuk Ritual} Adat, Mistis dan Pertanda

Anjing (Canis lupus) yang dimanfaatkan darahnya digunakan dalam upacara adat ritual dalam masyarakan Dayak Jelai Hulu Embulu Lima, untuk memberi sesaji kepada sang dewata. Darah anjing yang telah dicampur dengan tepung tawar disumpitkan ke langit dengan membaca doa-doa agar sesaji ini langsung mengarah dan diterima sang dewata. Adat istiadat ini disebut upacara adat tumbal sasar digunakan masyarakat Dayak Jelai Hulu Embulu Lima sebagai ketentraman dalam hidup. Selain itu 
kepala anjing digunakan sebagai sesaji dalam upacara adat pembangunan.

Babi (Sus barbanus) yang dimanfaatkan seluruh badannya untuk ritual, hampir semua ritual dalam masyarakat Dayak Jelai Hulu Embulu Lima menggunakan babi mulai dari acara pernikahan, hukuman adat, dan ritual-ritual lainnya. Selain di Desa Dayak Jelai Hulu Embulu Lima di daerah lain seperti masyarakat Dayak Kanayant Desa Babane Kalimantan Barat babi juga digunakan sebagai symbol ikatan antar keluarga dan penangkal roh jahat (Pilatus, 2017). Babi berdasarkan pendapat umum menyatakan bahwa bangsa babi merupakan hewan yang paling awal dijinakan, bukan kucing ataupun anjing. Hal ini terbukti dengan adanya penemuaan lukisan dan ukiran babi yang berumur lebih dari 25.000 tahun yang lalu (Agung, 1993).

Ayam (Gallus gallus domesticus), yang dimanfaatkan darah dan bulu. Ritual adat mandik bunting di masyarakat Dayak Jelai Hulu Embulu Lima masih sering dilakukan secara turun temurun, tujuan dari ritual adat ini untuk membuang sial terhadap bayi yang di dalam kandungan maupun ibu yang mengandung. Darah ayam yang telah di campur bulu ayam, minuman tuak atau minuman berakohol yang dijadikan satu dalam wadah, untuk dimandikan ke ibu hamil agar saat proses lahiran tidak ada hambatan.

Burung hantu (Otus magicus) yang dimanfaatkan Dayak Jelai Hulu Embulu Lima sebagai pertanda dari suaranya.
Burung hantu ini atau Buak dipercaya membawa musibah dan pertanda akan adanya orang meninggal dikampung tersebut. Burung ini memiliki jenis suara yang berbeda-beda terdapat kepercayaan salah satu dari bunyi suara dari burung ini yang membawa musibah, bunyi dari burung ini terdengar seperti tulang kulit yang artinya kematian. Selain di Desa Dayak Jelai Hulu Embulu Lima di daerah lain seperti masyarakat Dayak Bakati Desa Seluas Kalimantan Barat burung hantu ini dianggap mistis, masyarakat ini beranggapan bahwa burung hantu merupakan jelmaan dari mahluk halus sehingga banyak ditakuti sebagian masyarakat, yaitu sebagai memberi pertanda buruk (Rusmiati, 2018).

Cicak (Hemidactylus platyrus) yang dimanfaatkan Dayak Jelai Hulu Embulu Lima sebagai pertanda atau mistis. Kepercayaan masyarakat terhadap cicak yang jatuh ketubuh atau pun kotorannya sebagai pertanda kemalangan atau musibah. Masyarakat Dayak Belangin Kalimantan Barat juga menggunakan cicak sebagai pertanda atau diberi anugrah menyembuhkan penyakit dan harus memperoleh mimpi mengenai karunia penyembuhan (Heningsih, 2018).

Ritual atau upacara adat berayah yang dipercaya masyarakat Dayak Jelai Hulu Embulu Lima sebagai ritual untuk menyembuhkan maupun mengobati orang yang sakit. Ritual adat berayah ini dipimpin seorang yang dipercaya memiliki keahlian khusus untuk menyembuhkan orang sakit, pemimpin 
ritual adat ini disebut balin atau belian. Orang yang telah mengikuti ritual adat berayah harus berpantang pantiq atau tidak boleh melanggar semua pantangan. Ikan lele (Claris batracus) dipercaya masyarakat Dayak Jelai Hulu Embulu Lima sebagai pantangan untuk tidak memakan atau mengkonsumsi apabila menjalani upacara adat Berayah. Bekamet yaitu ritual lanjutan selama dalam pengobatan dilarang mengkonsumsi jenis ikan ini.

\section{Pemanfaatan Satwa untuk Kesenian}

Hubungan yang erat antara manusia dan hewan dari zaman ke zaman, yang telah dilibatkan dalam semua budaya sebagai cerminan dari sifat kemanusiaan yang melambangkan karakteristik masyarakat dan individu (Alves, 2012). Pemanfaatan satwa yang bernilai seni oleh masyarakat suku Dayak Jelai Hulu Embulu Lima, berdasarkan hasil penelitian bagian yang dapat dijadikan sebagai seni yaitu tengkorak hewan, tulang maupun jenis suara burung.

Beberapa satwa yang dimanfaatkan sebagai pajangan di dalam rumah baik dari segi tulang, paruh, bulu, suara, tulang kepala, dan tanduk. Burung kacer dan tekukur dipelihara masyarakat karena memiliki suara yang khas. Bagian satwa lain yang dimanfaatkan seperti tulang, paruh, bulu, dan tanduk yang dipajang di dalam rumah, hal ini merupakan pesan kepada yang melihat bahwa mereka pernah mendapatkan hewan tersebut.

\section{Bagian Hewan yang Dimanfaatkan}

Pemanfaatan hewan oleh masyarakat Dayak Jelai Hulu Embulu Lima di Desa Mekar Utama ini yaitu mulai dari seluruh badan sampai pada organ-organ tubuh lainnya. Pemanfaatan bagian-bagian hewan ini dapat dilihat pada gambar 1 .

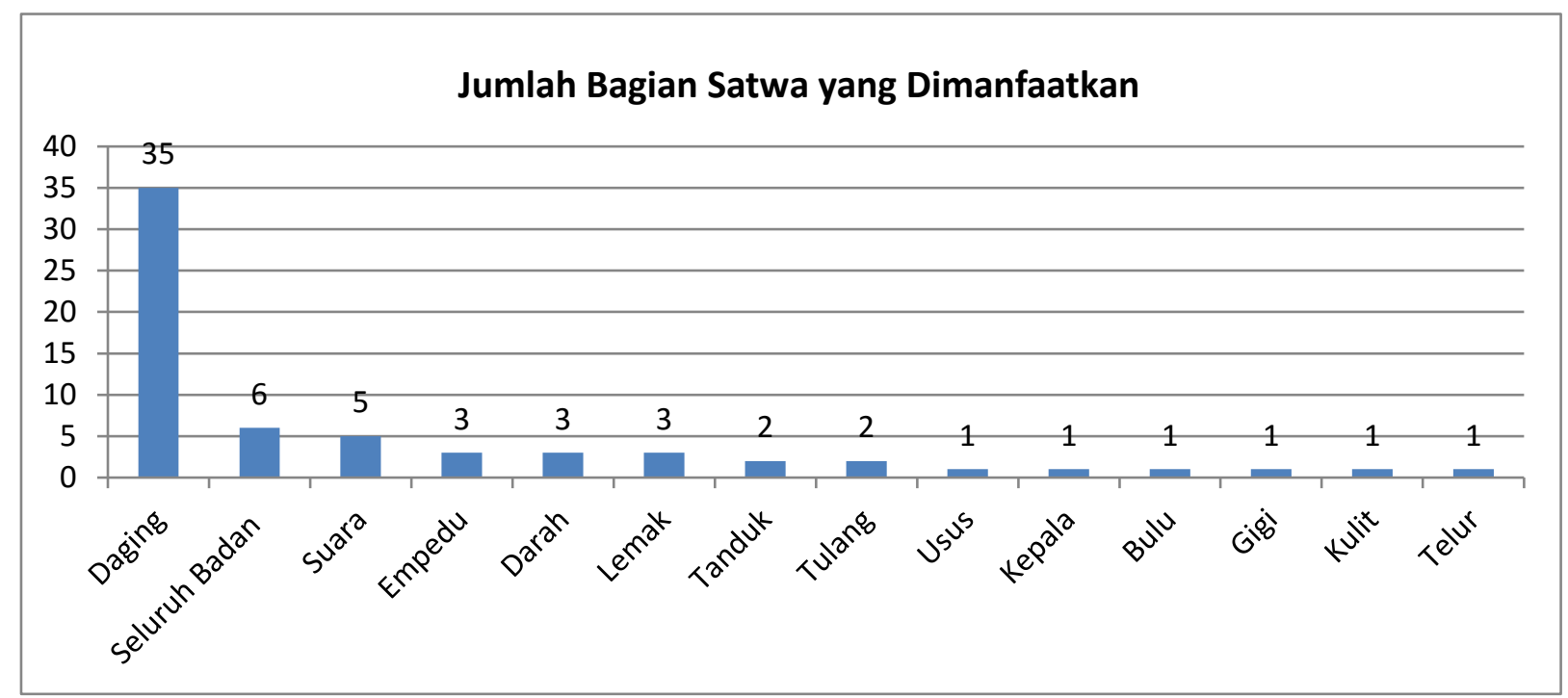

Gambar 1. Diagram Bagian Satwa yang Dimanfaatkan (Diagram of the parts of the Animal are Utilized) 
Berdasarkan gambar 1 terlihat pemanfaatan terbanyak yaitu pada pada bagian daging sebanyak 35 . Pemanfaatan seluruh tubuh sebanyak 6 , pemanfaatan suara sebanyak 5, pemanfaatan empedu, darah, dan lemak sebanyak 3, dan pemanfaatan tanduk dan tulang sebanyak 1. Tingginya presentase pemanfaatan satwa untuk daging dikarenakan satwa merupakan sumber pemenuhan kebutuhan protein yang digunakan setiap hari oleh masyarakat Dayak Jelai Hulu Embulu Lima.

\section{KESIMPULAN}

Berdasarkan hasil penelitian dari etnozoologi oleh suku Dayak Jelai Hulu Embulu Lima di Desa Mekar Utama Kecamatan Kendawangan Kabupaten Ketapang dapat disimpulkan sebagai berikut :

1. Jumlah jenis satwa sebanyak 48 jenis dari 45 famili yang dimanfaatkan. Famili-famili tersebut rata-rata setiap famili hanya terdiri atas satu spesies, kecuali untuk famili Cervidae, Columbidae, Muscicapidae, Trionychidae, dan Gekkonidae, yang memiliki masing-masing dua spesies. Tingkat kelas yang diperoleh sebanyak delapan kelas satwa yang dimanfaatkan yaitu, Mamalia, Aves, Amfibi, Reptil, Insecta, Molusca, Pisces, dan Crustacea. Kelas terbanyak yang dimanfaatkan adalah jenis Mamalia yang terdiri dari 14 spesies.

2. Jumlah pemanfaatan bervariasi mulai dari pemanfaatan konsumsi sebanyak $58 \%$, pengobatan sebanyak $17 \%$, ritual adat sebanyak 5\% atau mistis sebanyak 6\%, dan nilai seni sebanyak $14 \%$.

3. Bagian satwa yang dimanfaatkan meliputi daging, seluruh badan, suara, empedu, darah, lemak, tanduk, tulang, usus, kepala, bulu, gigi, kulit, dan telur. Bagian yang sering dimanfaatkan yaitu pada bagian daging yang digunakan sebanyak 35 pemanfaatan.

4. Cara pengolahan dan pemanfaatan satwa yang bervariasi oleh masyarakat Dayak Jelai Hulu Embulu Lima mulai dari ritual, mistis, konsumsi, pengobatan dam bernilai seni. Cara pengolahan antara lain, dimasak, ditumis, digoreng dan dibakar. Cara pemanfaatan antara lain, diminum, dioleskan dan dimakan.

\section{SARAN}

1. Pengetahuan tentang pemanfaatan hewan perlu didokumentasikan secara tertulis dan sebaiknya dapat diturunkan kegenerasi lebih muda.

2. Kurangnya pengetahuan masyarakat tentang status perlindungan satwa sehingga perlu dilakukan sosialisasi mengenai status konservasi satwa.

3. Salah satu yang upaya yang dapat dilakukan untuk melestarikan satwa yang dilindungi ialah mengingatkan kembali nilai-nilai luhur yang dimiliki, untuk memperkecil kemungkinan kelangkaan satwa yang mereka butuhkan.

\section{UCAPAN TERIMAKASIH}

Terimakasih penulis ucapkan kepada PT. HKI (Hutan Ketapang 
Industri), yang telah membantu banyak dalam hal material sehingga penelitian ini dapat terlaksanakan dan penulis dapat menyelesaikan perkuliahan sarjana kehutanan.

\section{DAFTAR PUSTAKA}

Agung. 1993. Kenangan Masa Lampau Zaman Kolonial Hindia Belanda Dan Zaman Pendudukan Di Bali. Yayasan Obor Indonesia. Jakarta.

Alves. 2012. Relationships Between Fauna and People and The Role of Ethnozoology in Animal Conservation. Etnobio Conserv $1: 2$

[Bappenas] Badan Perencanaan Pembangunan Nasional. 2003. Indonesia Biodiversity Strategy and Action Plan (IBSAP) 2003 2020. Jakarta. Bappenas.

Heningsih M, Anwari MS, dan Yani A. 2018. Kajian Etnozoologi Untuk Obat - Obatan Masyarakat Dayak Belangin Di Desa Mu'un Kecamatan Ngabang Kabupaten Landak. Fakultas Kehutanan Universitas Tanjungpura. Pontianak Vol 6 (3) : 647-653.

Indrawan M dan Primack RB. 2007. Biologi Konservasi. Yayasan Obor Indonesia. Jakarta.

Pilatus, Kartikawati SM, Anwari MS. 2017. Etnozoologi Suku Dayak Kanayant Di Desa Babane Kecamatan Samalantan Kabupaten Bengkayang. Fakultas Kehutanan Universitas Tanjungpura. Pontianak Vol.5 (3) : 858-867.

Suparlan P. 2005. Suku Bangsa dan Hubungan Antar Suku Bangsa. Cetakan Kedua. Yayasan
Pengembangan Kajian Ilmu Kepolisian Press, Jakarta: 11-12.

Zayadi H, Azrianingsih R dan Sjakoer NAA. 2016. Pemanfaatan Hewan Sebagai Obat-Obatan Berdasarkan Persepsi Masyarakat Di Kelurahan Dinoyo Malang. University Of Islam Malang. Indonesia Vol.4 